\title{
PRELIMINARY REPORT ON THE SIXTEENTH EXCAVATION SEASON OF THE ARCHAEOLOGICAL EXPEDITION TO WAD BEN NAGA
}

\author{
Pavel Onderka ${ }^{1}$ - Vlastimil Vrtal - Jiř́ Honzl
}

\begin{abstract}
During its seventeenth excavation season, the Archaeological Expedition to Wad Ben Naga continued with the exploration of the so-called Palace of Queen Amanishakheto at Wad Ben Naga (WBN 100), as well as with the excavation and protection of the kom located behind the rail track. During the season, the complex of the so-called Isis Temple at Wad Ben Naga (WBN 300) began to be explored. Based on the previous magnetometric survey, a Meroitic kiosk (WBN 390) was unearthed and documented.
\end{abstract}

KEY WORDS: Wad Ben Naga - Meroitic architecture - Meroitic kiosk

\section{Introduction}

The sixteenth excavation season of the Archaeological Expedition to Wad Ben Naga took place between 6 March and 2 April 2018. The archaeological tasks, as well as conservations tasks, were launched on 10 March and were concluded on 30 March 2018.

The mission was headed by Pavel Onderka (field director) and Juweriya Osman Mohamed Zain (inspector of the National Corporation for Antiquities and Museums). It further consisted of Vlastimil Vrtal (archaeologist), Jiří Honzl (pottery specialist) and Gabriela Jungová (anthropologist).

1 Contact: Pavel Onderka \& Vlastimil Vrtal \& Jiří Honzl, National Museum - Náprstek Museum of Asian, African and American Cultures, Ancient Near East and Africa Collection, Prague, Czech Republic; e-mail: pavel_onderka@nm.cz, vlastimil_vrtal@nm.cz, jiri_honzl@nm.cz. The article was written within the framework of the project "The building program of king Natakamani and Queen Amanitore" supported by the Czech Science Foundation (grant no. 18-00454S). The Archaeological Expedition to Wad Ben Naga wishes to express its sincerest thanks and gratitude to the National Corporation for Antiquities and Museums, namely to Dr. Abdel-Rahman Ali Mohamed, Juweriya Osman Mohamed Zain and Iglal Malik, and Dr. Nasreldin Shulgami, the Honorary Consul-General of the Slovak Republic in the Sudan.

This work is licensed under the Creative Commons Attribution-Noncommercial-No Devivs 3.0 License 
The tasks of the season focused on [1] the initial phase in the exploration of the socalled Isis Temple (WBN 300), namely the kiosk WBN 390 located in front of the temple; [2] the continued excavation of the Palace of Queen Amanishakheto (WBN 100), [3] the continued exploration of the endangered area behind the rail track (focused on the excavation of burial pits and anthropological examination of human remains discovered in the given area).

\section{[1] Exploration of the so-called Isis Temple (WBN 300)}

Based on the geomagnetic survey carried out by the Eastern Atlas company during the fifteenth excavation season (early December 2017; Onderka et al. 2018), remains of a kiosk (numbered as WBN 390) were identified in front of the anticipated location of the so-called Isis Temple (WBN 300; Pl. 1; Ullrich et al. 2018). Two trenches, namely T56 and T61, were excavated in the area south of the Typhonium (WBN 200) and west of the anticipated so-called Isis Temple (WBN 300).

\section{Trench T56}

The trench T56 (final dimensions $10 \times 13$ m; Fig. 1, Pl. 2) was set to cover the total extent of the kiosk WBN 390. The remains of a rectangular structure, with the ground plan of ca. $735 \mathrm{~cm}$ by $575 \mathrm{~cm}$, did not exceed three courses of red bricks above the level of the terrain. Foundations of the structure were cut into the local bedrock (sāra). Depressions

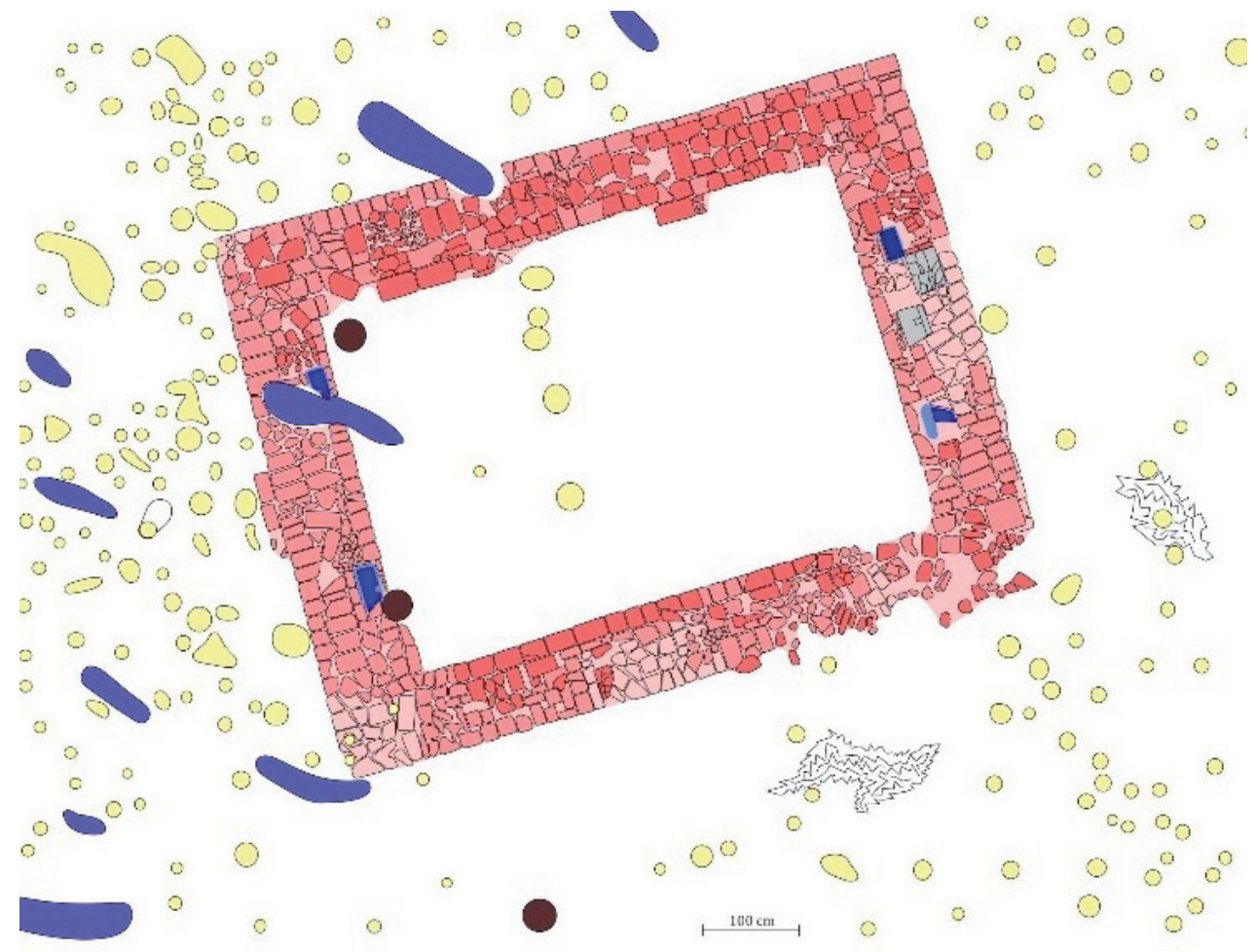

Fig. 1 Top plan of Trench T56 at the end of excavations (Drawing: Pavel Onderka). 
- natural, as well as artificial - in the bedrock were filled with masonry if they were under the walls. The walls show a low quality of the brick work. The material used for the preserved part of the kiosk appears to have been re-used. Possibly, the waste material from the construction of the proper temple WBN 300 was used. It appears that the Egyptian cubit (ca. $52.3 \mathrm{~cm}$ ) was used as the basic unit of measurement for the construction of the kiosk, as was the case of kiosks of Kushite temples dedicated to Egyptian gods. If the dimensions of the kiosk are calculated in Egyptian cubits, it is evident that the structure was laid out quite precisely (despite the quality of masonry). The outer dimensions of the longer and shorter walls were 14 and 11 cubits, respectively. The kiosk is expected to have been aligned according to the axis of the so-called Isis Temple (WBN 300). Its western shorter side is aligned with the outer western wall of the Typhonium. Doors were inserted into the western and eastern walls of the kiosk.

If we look on the list of Kushite kiosks, we quickly realize that there were two major periods in which this type of structure was constructed. The first period was the Twenty-Fifth Dynasty, while the second period was the $1^{\text {st }}$ century CE, or the period around the $1^{\text {st }}$ century CE. The kiosk WBN 390 is thus the most recent addition to a series of kiosks and kiosk-like structures either associated (based on epigraphic evidence) with King Natakamani and Queen Amanitore, or dated to the $1^{\text {st }}$ century CE (cf. Hinkel 1989; Török 2002: 273ff).

\section{Ritual deposits}

Three ritual deposits (Fig. 2; Pls. 3 and 4) laid into an artificial hole in the bedrock were discovered along the western side of the structure. Each of the deposits - two inside and one outside of the kiosk - contained a set of miniature vessels placed at the bottom of the hole, a mud brick fragment or a mud brick object placed above them and potsherds of a complete broken large vessel on top. The sets of miniature vessels in the first and second deposits contained 21 specimens, while the third set contained 22 specimens (one of which was imperfect and broken). The miniature vessels in each of the deposits were slightly different both in their sizes and their shapes. One may assume that there might have been some symbolism in the total number.

This assumption was supported by discoveries from other sites. As a matter of coincidence, a similar set of miniature vessels was discovered at the same time by the German mission working at Naga. There 42 vessels were found in a single context, the number being the double of the numbers known from Wad Ben Naga. Other sites that produced similar discoveries are Dangeil and Royal City of Meroe. ${ }^{2}$ Three out of the four discoveries of miniature vessels are more or less securely connected with structures of Natakamani and Amanitore and may reflect ritual practises of the given period.

Each deposit of miniature vessels was covered by larger open vessel of different form. Vessel Deposit 1/0 was conical deep round based bowl (WBN sub-form B1b2), which belongs among common pottery shapes encountered both at Wad Ben Naga and elsewhere, especially in the southern part of the Meroitic kingdom (inter alia Hintze et al. 1993: Abb. 382, 390; Fitzenreiter et al. 1999: Abb. 46, a.3; Grzymski 2003: fig. 21, P.121, fig. 22, P.97; El-Tayeb - Kolosowska 2005: fig. 22, a; Malykh 2017: fig. 7, r-s.). Vessel

2 Personal communications with Karla Kroeper (Naga; Staatliches Museum der ägyptischen Kunst, Munich), Julie R. Anderson (Dangeil; The British Museum, London) and Hwida Mohammed Adam (Meroe; University of Khartoum). 


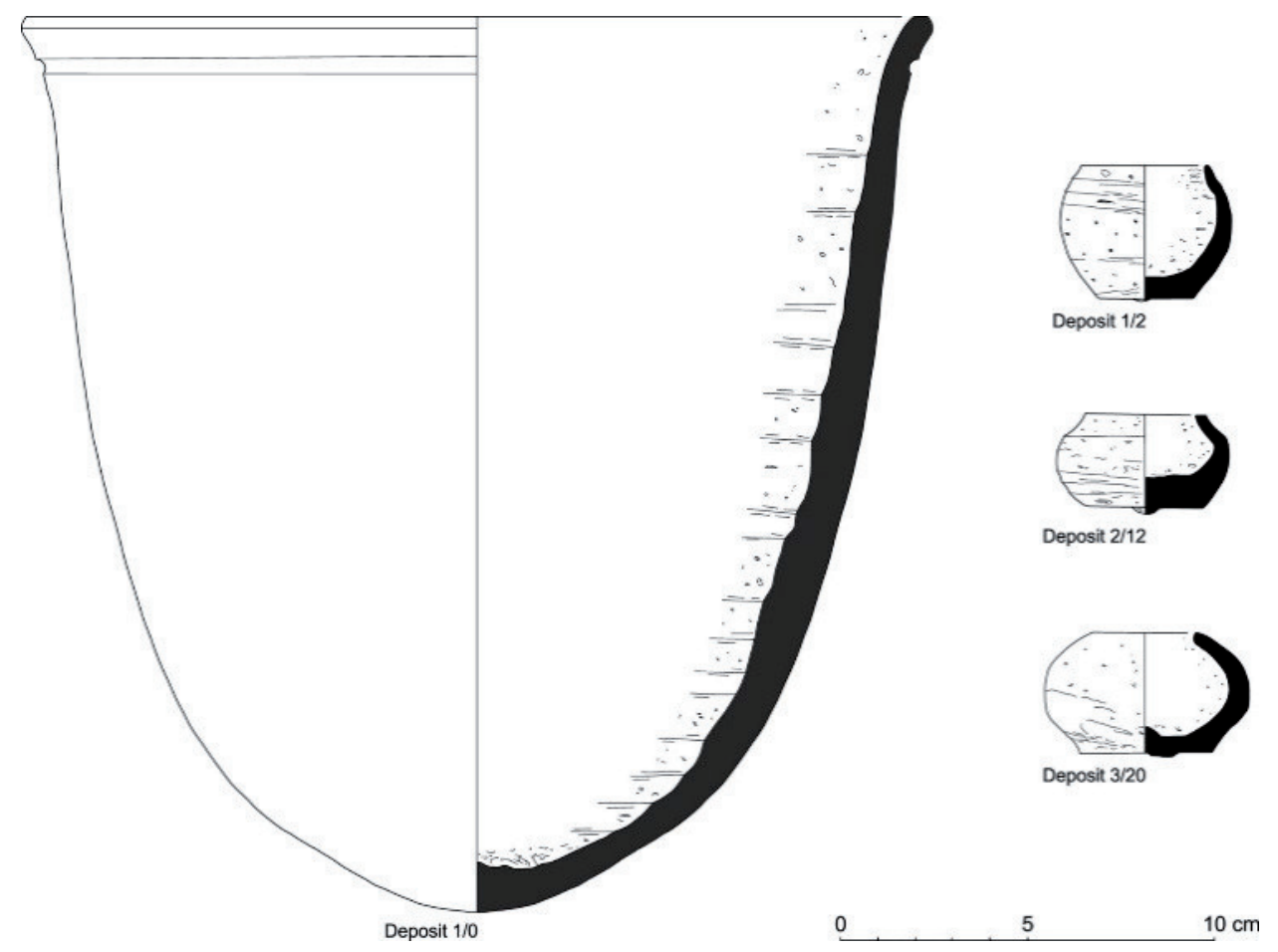

Fig. 2 Representative samples of pottery from all three deposits (Drawing: Jiř́i Honzl).

Deposit 2/0, also represented quite usual Meroitic form, in this case tall cup (WBN form C3). However, it was remarkable by its size, which was larger than in the case of most other similar vessels (cf. e.g. Edwards 1998: fig. 6.17, no. 8902; Edwards 1999: Pl. XVIII, no. 820). Specimen Deposit 3/0 was a unique vessel, so far without a close parallel at Wad Ben Naga or elsewhere. Nonetheless, it is to a certain degree similar to open conical vessels (WBN form M8), from which it differs mainly by tall, almost cylindrical shape of the body. Being probably even older, vessels of form M8 were regularly appearing in contexts datable to the $1^{\text {st }}$ century $\mathrm{BCE}$ and $1^{\text {st }}$ century $\mathrm{CE}$, but seem to have been utilised in limited amounts even after. Small vessels found as the main contents of the deposits possibly represent miniaturised and generalised versions of some of the common forms of Meroitic vessels, to which some of them could be compared tentatively. So far, only a handful of comparable miniature vessels were published from other Meroitic sites (Macadam 1955: 162, no. 0295, fig. 55, no. 0352; Shinnie - Bradley 1980 fig. 28, no. 8; Robertson - Hill 2004: Pl. IVb, no. 2.). At Wad Ben Naga, torso of another possibly comparable vessel was recovered from the Typhonium (WBN 200).

The term foundation deposit was not used here intentionally as the deposits do not seem to follow the outlines of the structure in question. However, their relative position - they are more or less in one line - may indicate that they possibly delimited a sacred place of a different character, possibly a sacred district. Only future excavation in the area between the kiosk and the Typhonium may possibly shed some more light on the problem. One of the working theories may be that the deposits delimit the area levelled 
before the outstanding building program of Natakamani and Amanitore was begun in this part of the site.

In the western half of the trench a cemetery, newly numbered as WBN C260, was discovered. The part covered by the square $\mathrm{T} 56^{3}$ contained three larger burials of young individuals, as well five children's burials. Inside and outside of the kiosk numerous postholes were identified.

\section{Trench T61}

The geometer survey also indicated a structure located further to the west of the kiosk WBN 390. The indication of some kind of structure being located in this part of the site appeared during the excavation of the tumulus WBN C204. Under the tumulus, directly on the sāra, carefully laid bricks - a wall, a terrace as in Naga or even a pylon as in Dangeil - were discovered. The area north of the tumulus WBN C204 is going to be excavated in the coming excavation season.

The trench T61 $(1.5 \times 15.0 \mathrm{~m})$ was located to the west of the trench T56, and was aligned according to the north side wall of the kiosk. The aim of the section was to determine presence of other structures located to the west of the kiosk on the temple axis, as suggested by the magnetometric prospection. An outer pylon could have been located in the given area. The trench yielded some structures (possibly walls), remains of which were of poor construction and combined different materials (larger sandstone blocks, broken bricks, stones, etc.).

\section{[2] Exploration of the Palace of Queen Amanishakheto (WBN 100)}

During previous excavation seasons, two baulks preserving original fill of rooms WBN 119 and WBN 121 in the Palace of Amanishakheto were excavated and provided valuable information on the kom's stratigraphy (Onderka et al. 2015: 98ff; Onderka et al. 2017: 116ff). The last baulk, which could be noted on the surface, as well as on field photos from 1960 (Pl. 5; Onderka 2016: nos. 35, bottom right; 36, left; 40, right), was situated in room WBN $118 \mathrm{~b}$ and bordered on a considerable fired brick debris from the west.

\section{Trench T57}

The dimensions of the baulk were ca $3.0 \times 1.5 \mathrm{~m}$. Trench T57 was thus set in this area, covering rooms WBN 118a, WBN 118b and WBN 128; in order to (1) prepare a section through the baulk and examine its stratigraphy, (2) examine the fired bricks debris and its relation to surrounding walls, (3) examine mudbrick wall WBN118a/118b and its relation to surrounding walls, and (4) establish floor levels in the rooms. The dimensions of the trench were $7.0 \times 4.0 \mathrm{~m}$.

In the western part of the trench, a thick layer of loose sand was removed, and the southern face of the baulk and destruction of wall WBN 118a/118b (FEA 191) uncovered. Besides occasional artefacts, such as potsherds, a globular faience bead (SM18/003) and a post-independence coin, the fill contained numerous fired brick fragments, some plastered, and several large fragments of sandstone blocks. The latter material likely

3 The exploration of the cemetery continued in the subsequent, i.e. seventeenth excavation season of the Archaeological Expedition to Wad Ben Naga. 
comes from the baulk and the brick debris. Several sandstone chips were found also in the western part of the baulk and under its uppermost layer [cf. Fig. 3 and 4]. Notably, sandstone was also retrieved in a considerable number from the baulk in room WBN 121, adding to finds of architectural elements in rooms WBN 156 and WBN 128 (Vercoutter 1962: 279-280). This indicates more extensive use of sandstone in the central part of the upper storey(s) of the palace than had previously been assumed.

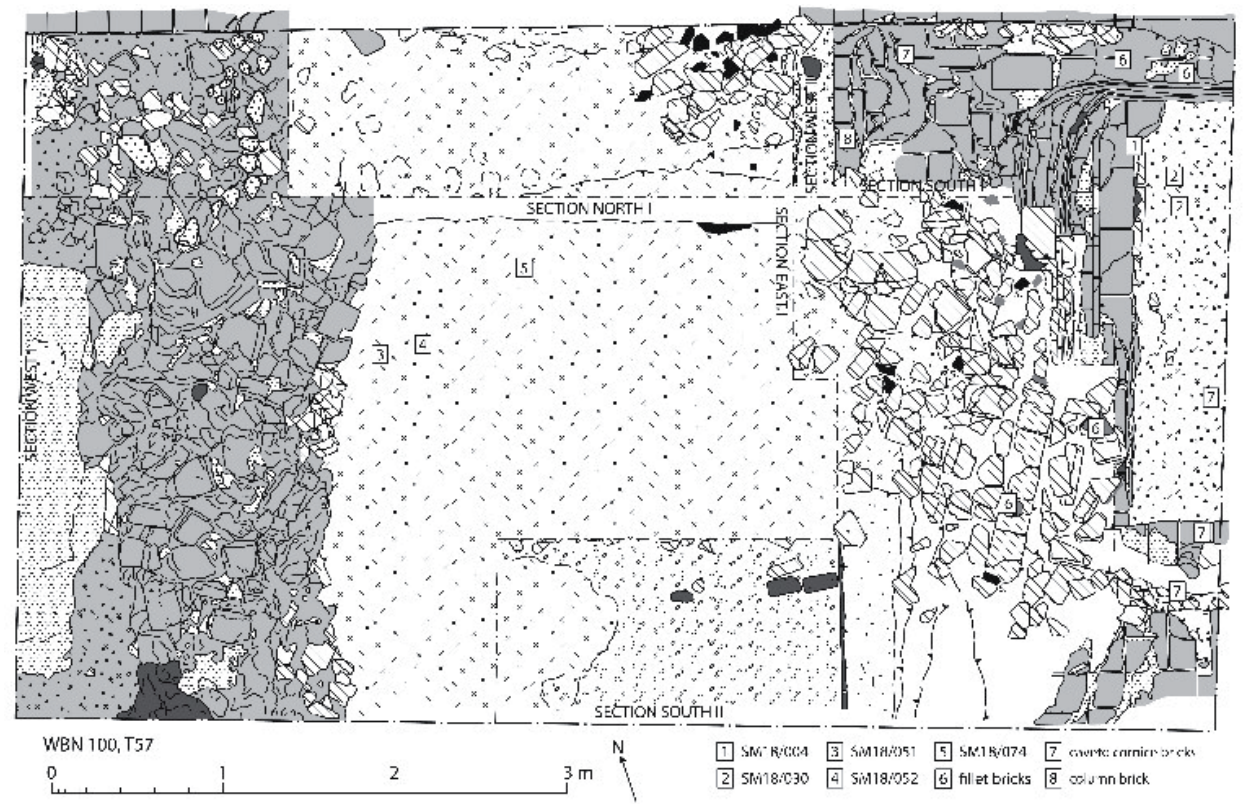

Fig. 3 Top plan of trench T57 at the end of excavations (Drawing: Vlastimil Vrtal).

A section through the baulk was prepared in its southern face, $1.0 \mathrm{~m}$ from the wall WBN 118b/121 [Fig. 4, Pl. 6]. In the debris from the baulk, two pounders (SM18/051, 052) and an iron (hook) nail (SM18/074) were found. The stratigraphic situation was similar to those encountered in the other baulks. The debris accumulated from the east and the north. The uppermost layer consisted of (1) a thick layer of white nodules, likely representing eroded plaster and mortar, with occasional sandstone and brick fragments (particularly in the lower part) and no artefacts (FEA 189). Below, (2) a compact layer of mudbrick and fired brick fragments representing the main destruction debris from the surrounding walls was situated (FEA 192); overlying (3) a compact layer of soil, sand, small stones, pebbles and white nodules with some anthropogenic material (FEA 193). Under this layer, (4) a well-defined layer of soil, sand and ash with numerous charcoals, animal bones (some attributed to bovines) and plant remains was situated (FEA 194). A sample of charcoal (B18-037) and plant remains (B18-036), the latter much similar in nature to those in the ash layer at kom H (Onderka et al. 2016: 107, fig. 1), were taken for analyses. (5) Two distinctive horizons of accumulated soil, sand, pebbles and small stones followed, containing a few potsherds (FEAs 195-196); overlying (6) a thin compact horizontal layer of white nodules, likely representing eroded plaster from the surrounding walls or the ceiling (FEA 197). A well-defined 

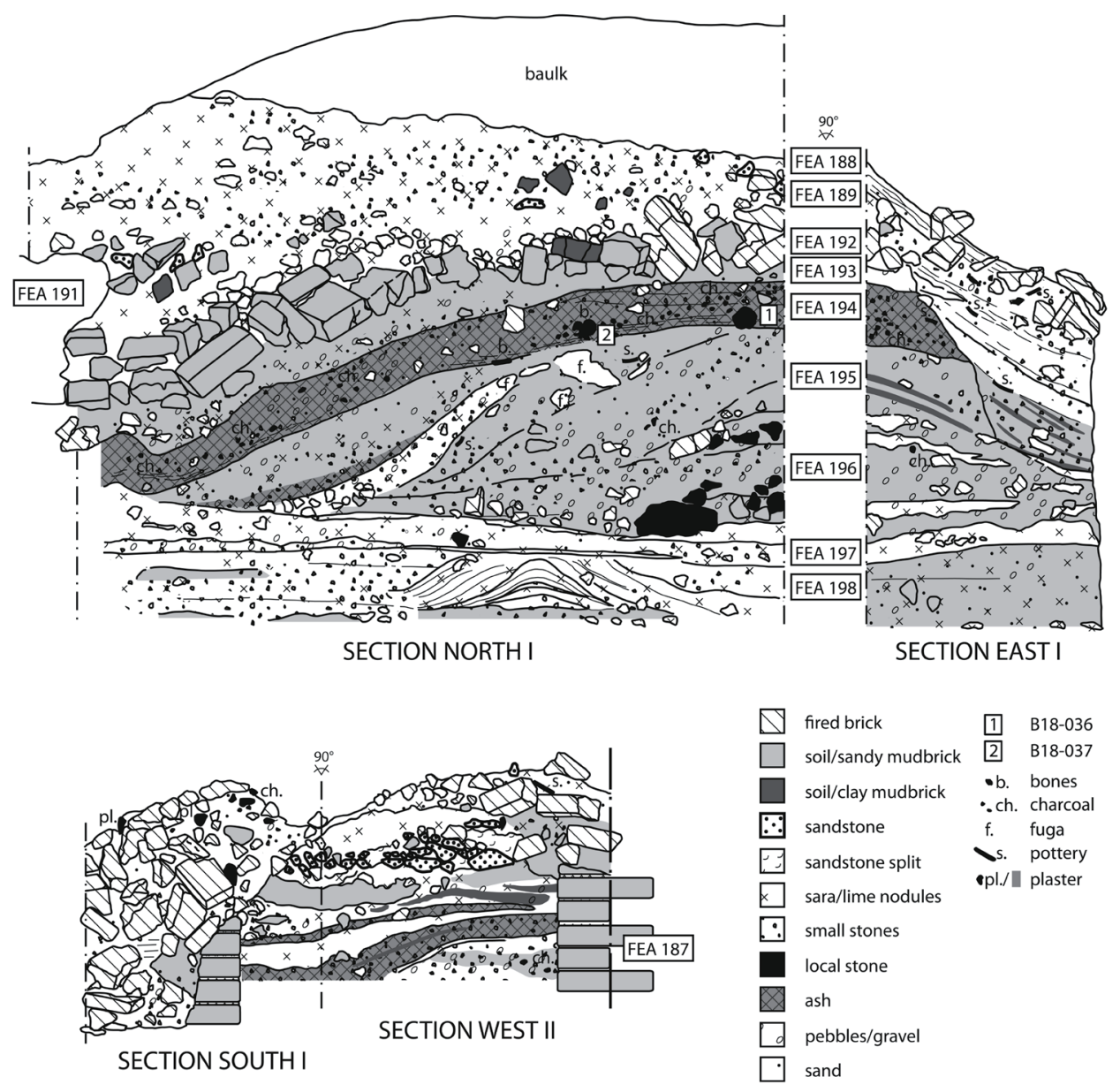

WBN 100, T57

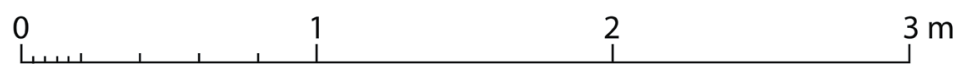

Fig. 4 Sections through the baulk preserving the original fill of room WBN 118b (Drawing: Vlastimil Vrtal).

floor could be noted below; $29 \mathrm{~cm}$ higher than the floor level recorded in rooms WBN 119 and WBN 121. The material forming the floor consisted of a compact mixture of soil and bedrock (FEA 198). In the southern part of the trench, a test pit was set and $0.5 \mathrm{~m}$ of the floor removed, revealing a loose fill of sand, gravel and ash (FEA 199); much similar to fill recorded in rooms WBN 120 and WBN 121, except that it contained little anthropogenic material.

Similarly to the other baulks, the one in trench T57 showed gradual accumulation of debris in the room; it differed, however, in a small proportion of debris from walls and higher proportion of loose material such as gravel and ash. It is difficult to ascertain the reason for this difference and the origin of the loose material. It could come from rooms at a higher level, but this would likely necessitate destruction of intermediary walls, for 
which there was no evidence except for the thin layer of eroded plaster (FEA 197). It is thus possible that the material was deposited in the room at some late date, likely in connection with the construction of light wall WBN 118a/118b, which perhaps necessitated removal of a limited amount of the fill of the floor. This would be in concordance with radiocarbon dating of charcoal sample B18-037 to 54 BCE - 1 CE. ${ }^{4}$ Linking the material to squatting activity, for which the accumulation of ash and animal bones could also speak, is unlikely given the radiocarbon date, unless wood from architectural elements of disintegrating palace was used as fuel.

Light wall WBN 118a/118b, which was relatively well-preserved in 1960 (Pl. 5), had since disintegrated into a mass of fired bricks and mortar (FEA 191). On the edges of the debris, fired brick fragments were present that almost certainly come from the debris above, however. In the northern part, a test pit was set in order to uncover structural remains of the light wall and analyse its relation to wall WBN 118/121. Unfortunately, no regular brickwork was encountered after removal of ca. $0.8 \mathrm{~m}$ of debris and the digging was suspended. Nothing indicated that the light wall was bound with the main wall. The debris continued along wall WBN 118a/121 further to the west in a narrow strip; it was likely left in situ to serve as a ramp for workers during the Sudanese excavations. Fired brick fragments predominated in this debris.

Significant fired brick debris (FEA 188) dominated the eastern part of the trench. Beside fired brick fragments, large number of potsherds, both local and imports, as well as fragments of plaster were scattered on the surface; perhaps providing an image of the kom's original surface. The debris was overlying crossing of mudbrick walls (FEA 187), forming rooms WBN 118, 121, 127 and 128, and since 1959-1960 excavations, it spread also to the surrounding rooms. In the debris, several special type bricks were found, namely four fillet bricks, six cavetto cornice bricks and a single column brick. Cornice bricks had plaster preserved with decoration in yellow, blue and red; the same colours were extant on various plaster fragments. Presence of cornice bricks is notable; together with a find of cornice brick in room WBN 121 (Onderka et al. 2015), they might indicate an open area (courtyard?; cf. Fitzenreiter 1999: 126ff) or roofing on multiple levels in the central part of the palace. Towards room WBN 128, two faces of fired brick wall were preserved; the first consisting of nine courses of brickwork, the other, situated lower, of five courses (Pl. 7). On the latter, lime plaster was partly preserved. The presence of a compact section of fired brick casing was puzzling, as neither was aligned with the eastern face of the mudbrick wall WBN 118a/128. Both sections also partly rested on debris and sand, (which also prevented their cleaning). It may be suggested that the sections gradually slid into their present position from higher up, where they perhaps formed walls of the upper storey. Similarly puzzling was also the situation of the mudbrick walls of room WBN 128. At certain height, their preserved parts receded by ca $0.4 \mathrm{~m}$ and continued further up. The recess was covered with fired brick debris, which seemingly penetrated also under the upper sections of the walls. The bad state of preservation of these upper sections might provide an explanation; there is, however, also a possibility that the dent might have supported a barrel vault, not unlikely in an elongated magazine such as WBN 128. The floor of the room was reached ca $0.8 \mathrm{~m}$ below the floor level in WBN 118. From the debris above, a stone with three linear marks as from a rope (a pulley or sharpener?; SM18/004) and a fragment of sandstone with small torus moulding (SM18/030) were retrieved.

4 CRL18_213, at $\mathrm{P}=68.2 \%$; $99 \mathrm{BCE}-19 \mathrm{CE}$ at $\mathrm{P}=95.4 \%$. 


\section{Trench T60}

Another trench was set perpendicular to the southern exterior wall, $3.2 \mathrm{~m}$ from the south-eastern corner. The dimensions of the trench were $5.0 \times 1.5 \mathrm{~m}$. The aim of the trench in this area was (1) to examine "gelbe Farbreste" noted by Hinkel (Hinkel Sievertsen 2002: Pl. IX.75), (2) examine foundations of the southern main wall, and (3) test for the presence of the wall's debris.

The exterior wall was cleaned and documented. Relatively large area of lime plaster was still in situ, covering the face of the wall, as well as the protruding foundations. On the surface, there was a strong patina; remains of the yellow colouring could be noted, any information on the original decorative pattern was nevertheless lost. The foundations of the wall were laid on levelled bedrock (sāra) and consisted of a course of bricks laid inclined on their sides for levelling, and two to three courses of headers, the lowermost one consisting of complete bricks, as well as brick fragments. As already mentioned, the foundations protruded ca. $12 \mathrm{~cm}$ from the wall face.

Four vessels embedded in the bedrock were uncovered further to the south under the fill of wind-blown sand (FEA 101) and surrounded by mixture of sand, bedrock particles and ash (FEA 200). The vessels were filled with ash, charcoal and small stones, undoubtedly indicating their function as ovens. Samples of charcoal and the fill were taken for further analyses. The vessels embedded could be identified in two cases as a handmade neckless jar with roulette decoration and a wheel-made vat; the other two vessels were poorly preserved. No debris from the exterior wall was uncovered in the area.

\section{Spoil heap}

In connection to conservation works carried out in the palace, material from the southern spoil heap was utilised. In the course of digging for the material, a number of artefacts were retrieved and subsequently documented; namely pottery, a grinding stone (SM18/073) and several large yellow pigment "balls".

\section{[3] Continued exploration of the endangered area behind the rail track}

The works continued also at the kom located behind the rail track. The works focused on the excavations of the graves belonging to the cemetery WBN C220 located on top of the kom. The road which was originally crossing the kom and was relocated closer to the rail track during the fifteenth season was further bolstered. The drainages under the rail track in the vicinity of the temple district in the western part of Central Wad Ben Naga were cleaned and a small dam directing the stream of seasonal waters away from the kom behind the rail track was built in order to protect the structures located in the given area. The skeletal material from the cemetery WBN C220 was studied and documented.

\section{Conclusion}

The initial phase in the exploration of the so-called Isis Temple at Wad Ben Naga (WBN 300) brought to light another Meroitic kiosk, namely WBN 390, which is believed to have originally stood in front of the pylon of the proper temple. The kiosk is of rather modest dimension. In terms of dimensions, the kiosk in front of the Amun Temple at 
Naga may serve as the closest parallel, while in terms of ratio between the length and width the Dangeil kiosk is the closest. Three deposits containing an object made of mud, a broken large vessel and a series of miniature vessels were discovered in the course of exploration of the kiosk. The discovery has the potential to shed more light on the ritual practise during the reign of King Natakamani and Queen Amanitore.

In the Palace of Amanishakheto, the excavations cast light on the original stratigraphy in room WBN 118 and to some respect also on relation of the light wall in the room to the main walls of the building. Section through the baulk showed accumulation of material preceding the main destruction of the surrounding walls and composition of construction materials that had been used in the upper storey(s), including sandstone. The debris partly uncovered further to the east provided information on the likely character of the upper storey. Presence of cavetto cornice and column bricks was most notable. Floor levels in rooms WBN 118 and WBN 128 were recorded; fill of the floor in room WBN 118 was analysed and provided limited amount of artefacts that can be used for dating the construction of the building. In trench T60, evidence of secondary economic activities was recorded, providing information on their character and dating.

The works at the kom located behind the rail track focused on site management and protection of the monuments in this particularly volatile part of the site.

\section{Literature:}

\section{Edwards, David N.}

1998 Gabati-a Meroitic, post-Meroitic and medieval cemetery in central Sudan. Volume 1. Sudan Archaeological Research Society publication 3. BAR International Series 740. Oxford.

1999 Musawwarat es Sufra III: A Meroitic Pottery Workshop at Musawwarat es Sufra. Meroitica 17, 2.

\section{Fitzenreiter, Martin}

1999 „Wohnbauten des antiken Sudan - Struktur und Entwicklung“, in: Fitzenreiter, Martin - Seiler, Anne - Gerullat, Ines: Musawwarat es Sufra II. Die Kleine Anlage. Meroitica 17.1, Wiesbaden, pp. 105-157.

Fitzenreiter, Martin - Seiler, Anne - Gerullat, Ines

1999 Musawwarat es Sufra II: die Kleine Anlage, 17, 1.

\section{Grzymski, Krzysztof}

2003 Meroe Reports I. Mississauga.

\section{Hinkel, Friedrich}

1985 "Untersuchungen zu Bausubstanz, Architektur und Funktion des Gebäudes Meroe 245", in Altorientalische Forschungen 12, pp. 216-232.

1989 "Säule und Interkolumnium in der meroitischen Architektur. Metrologische Vorstudien zu einer Klassifikation der Bauwerke." Meroitica 10, pp. 231-267.

Hinkel, Friedrich W. - Sievertsen, Uwe

2002 The Archaeological Map of Sudan. Supplement IV. Die Royal City von Meroe und die repräsentative Profanarchitektur in Kusch. Berlin.

Hintze, Fritz - Priese Karl-Heinz - Wenig Steffen - Onasch Christian - BuschendorffOtto Gisela - Hintze Ursula 
1993 Musawwarat es Sufra. Band 1, 1: der Löwentempel. Textband. Berlin.

\section{Macadam, M. F. Laming}

1955 The temples of Kawa. II: history and archaeology of the site, 2 vols. Oxford.

Malykh, Svetlana E.

2017 "Late Meroitic pottery of Abu Erteila: local traditions and foreign influence. Bulletin de liaison de la céramique égyptienne“ 27, pp. 137-180.

Onderka, Pavel

2016 Wad Ben Naga Report I: An Introduction to the Site. Praha.

Onderka, Pavel - Vrtal, Vlastimil - Gatzsche, Alexander

2015 "Preliminary Report on the Ninth Excavation Season of the Archaeological Expedition to Wad Ben Naga", in: Annals of the Náprstek Museum 36/2, pp. 93110.

2017 "Preliminary Report on the Twelfth Excavation Season of the Archaeological Expedition to Wad Ben Naga", in: Annals of the Náprstek Museum 38/1, pp. 113122.

Onderka, Pavel - Vrtal, Vlastimil - Jungová, Gabriela

2018 "Preliminary Report on the Fifteenth Excavation Season of the Archaeological Expedition to Wad Ben Naga", in: Annals of the Náprstek Museum 39/2, pp. 137148.

Robertson, John H. - Hill Edna M.

2004 "The Meroitic pottery industry" in: Shinnie, Peter L. - Anderson Julie R. (eds): The capital of Kush 2: Meroë excavations 1973-1984, pp. 109-136.

Shinnie, Peter L. - Bradley Rebecca J.

1980 The capital of Kush 1: Meroe excavations 1965-1972. Meroitica 4. Berlin.

\section{el-Tayeb, Mahmoud- Kołosowska Elżbieta}

2005 "The Awlib Temple complex: Kom B and its pottery assemblage" in: Paner, Henryk - Jakobielski Stefan (eds): Gdańsk Archaeological Museum African reports, vol. 3, pp. 145-158.

Ullrich, Burkart - Onderka, Pavel - Vrtal, Vlastimil

2018 "Preliminary Report on the Geophysical Survey of Central Wad Ben Naga" in: Annals of the Náprstek Museum 39/2, pp. 119-136.

Vercoutter, Jean

1962 "Un Palais des «Candaces», contemporain d'Auguste (Fouilles à Wad-ban-Naga 1958-1960)", in: Syria 39, pp. 263-299. 


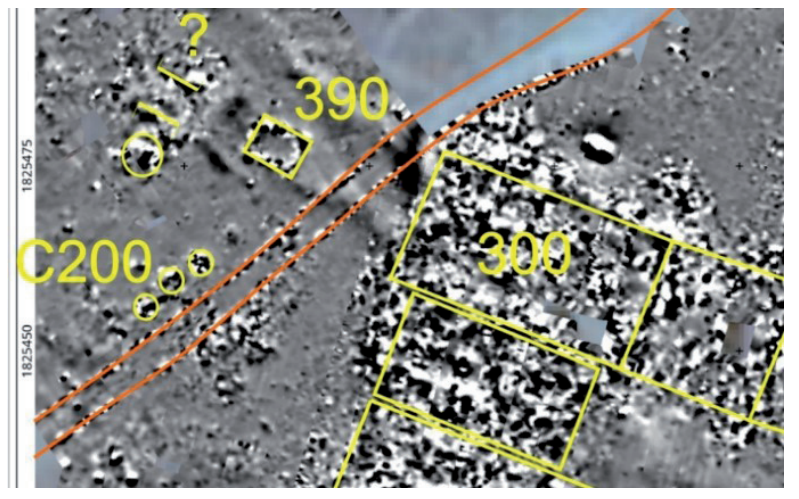

Pl. 1 Geomagnetic survey of the western part of Central Wad Ben Naga (Eastern Atlas).

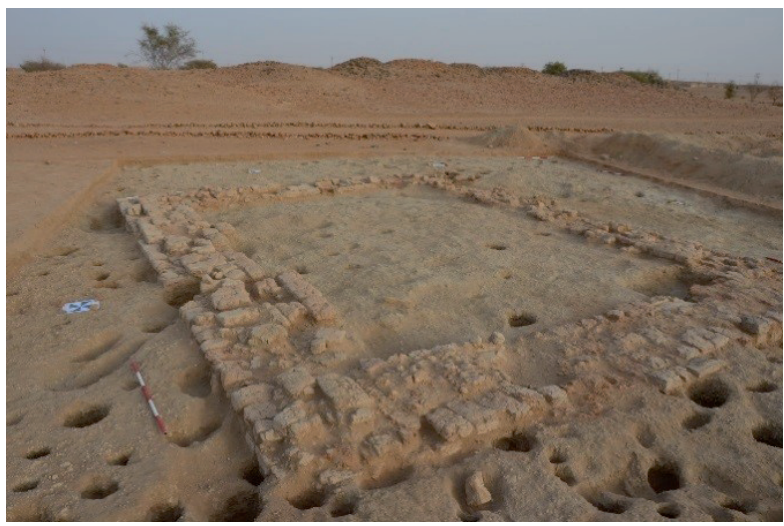

Pl. 2 Kiosk WBN 390 (Photo: Pavel Onderka).

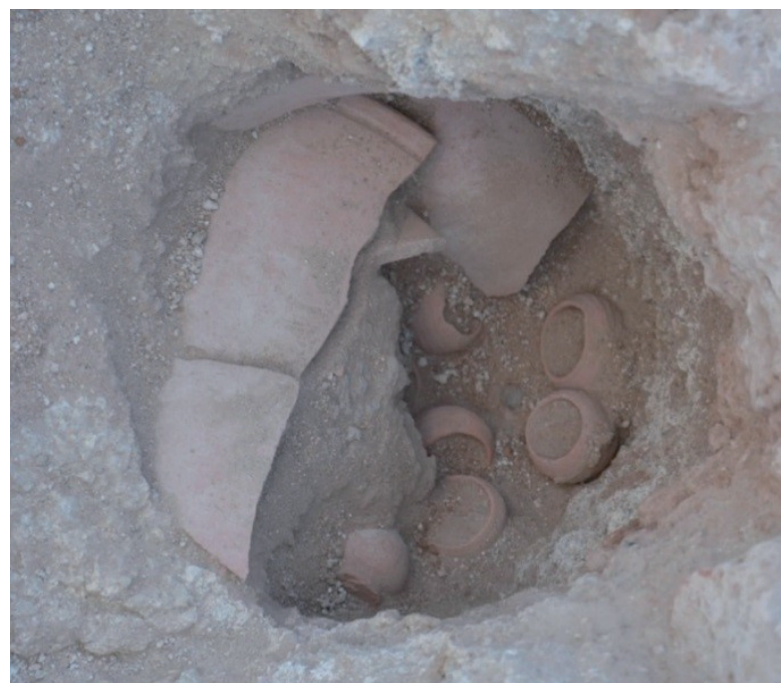

Pl. 3 Deposit 1 in situ (Photo: Pavel Onderka). 


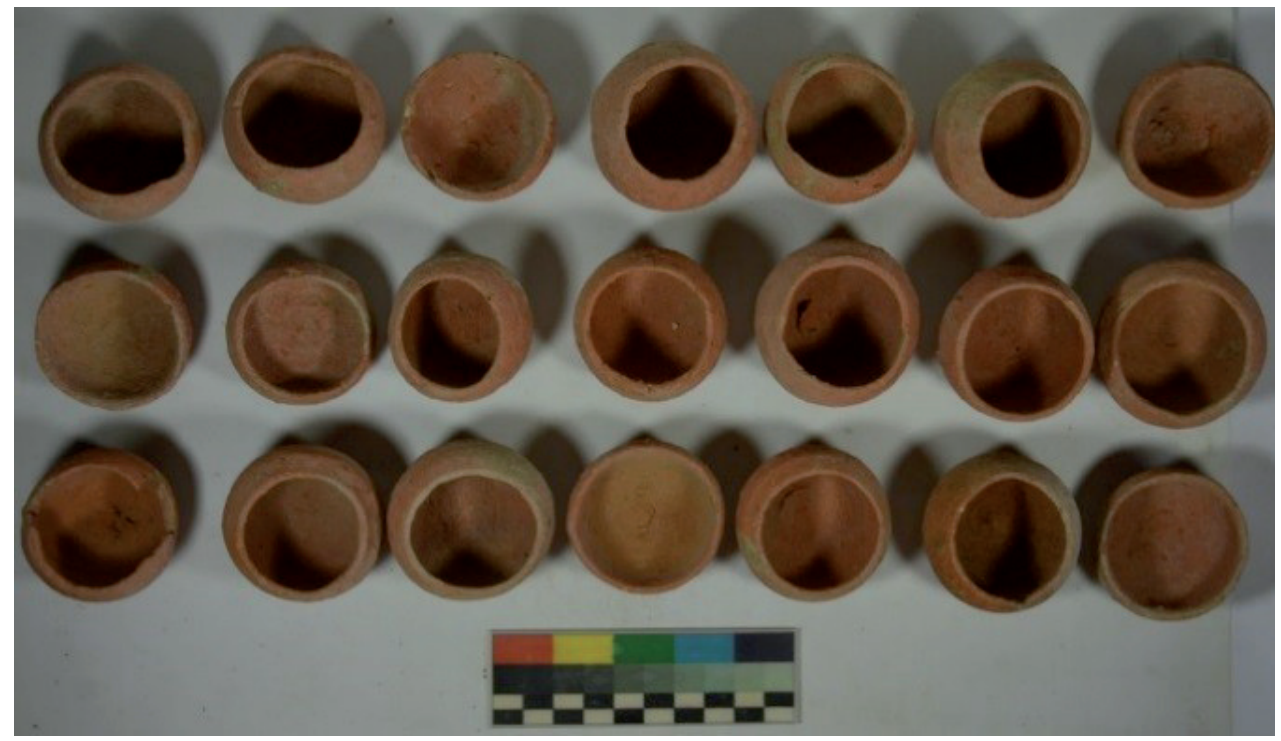

Pl. 4 Miniature vessels from Deposit 1 (Photo: Pavel Onderka).

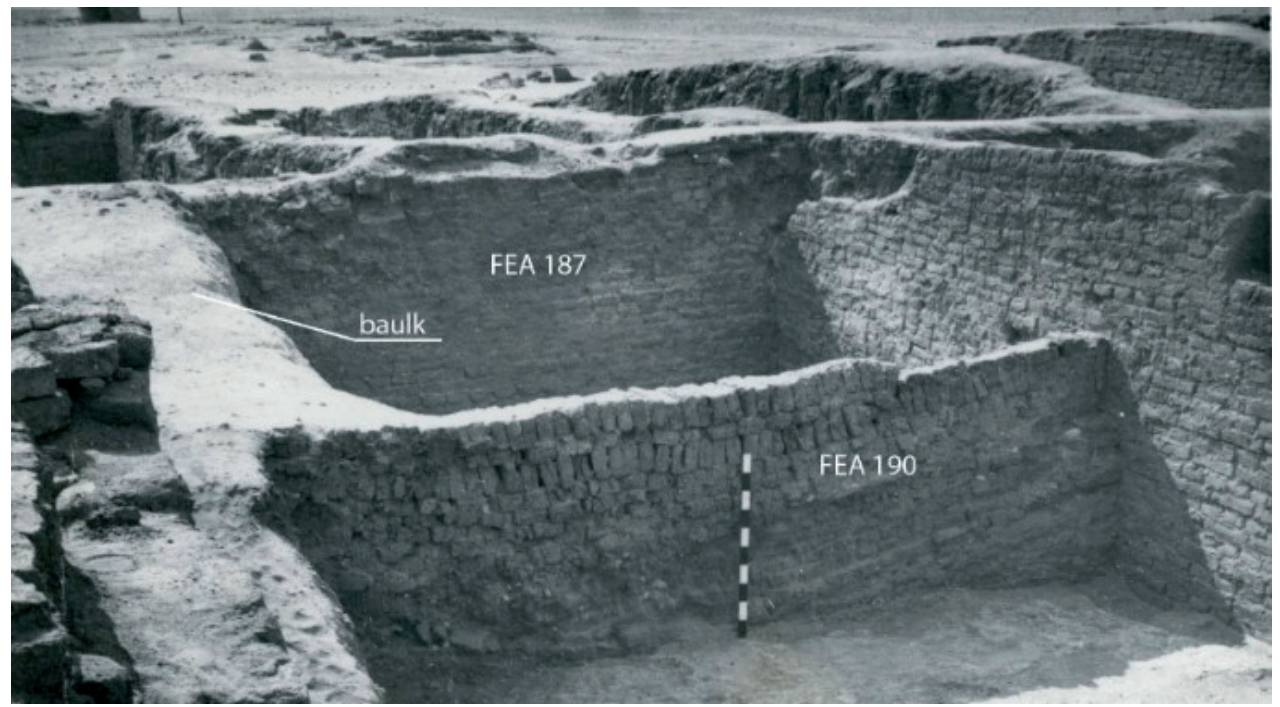

Pl. 5 Photograph from 1959-1960 excavations at the Palace of Amanishakheto, showing baulk in room WBN 118 and light wall WBN 118a/118b; view from the north-west

(Photo: Archive of SFDAS). 


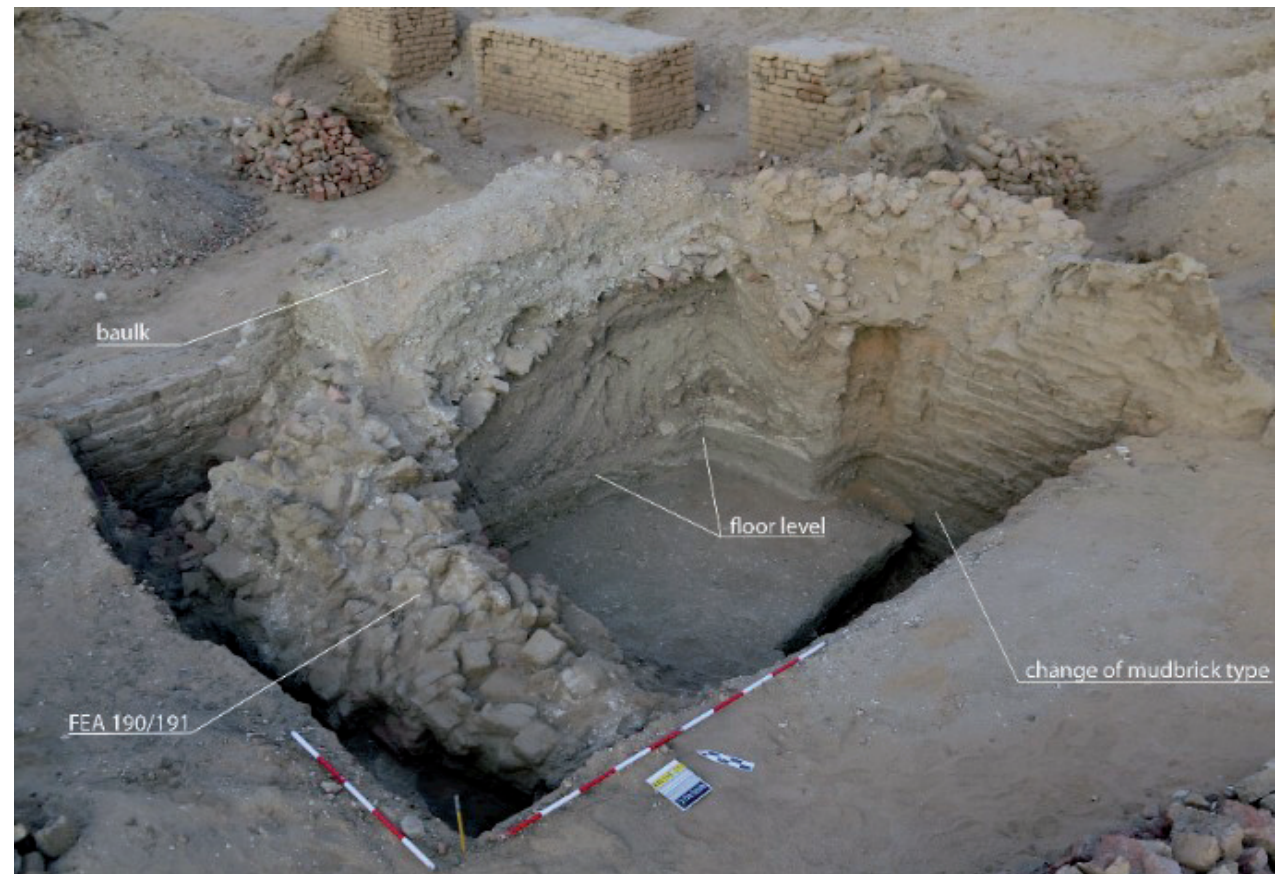

Pl. 6 Trench T57 at the end of excavations, showing the section through the baulk and destruction of wall WBN 118a/118b; view from the west (Photo: Vlastimil Vrtal).

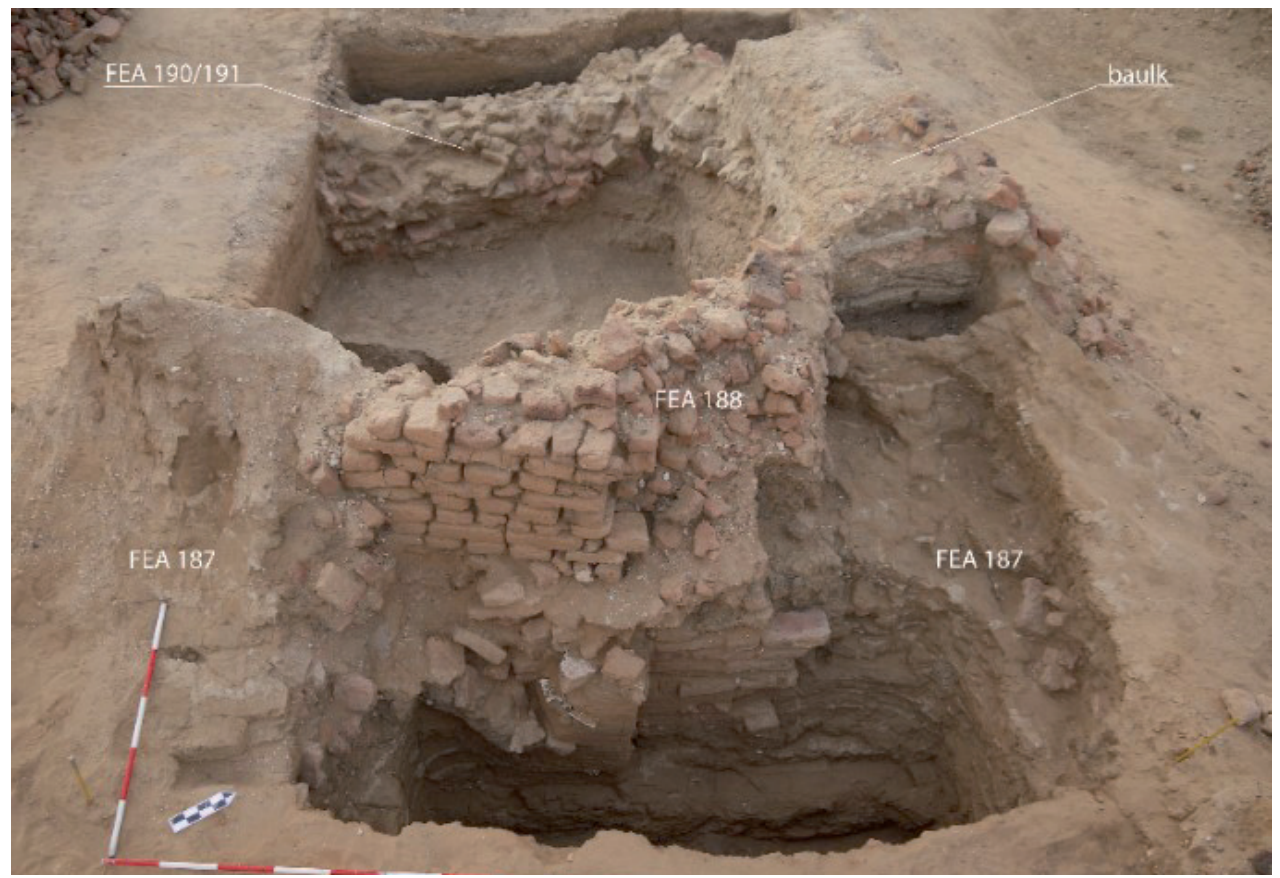

Pl. 7 Trench T57 at the end of excavations, showing the debris between rooms WBN 118 and WBN 128; view from the east (Photo: Vlastimil Vrtal). 


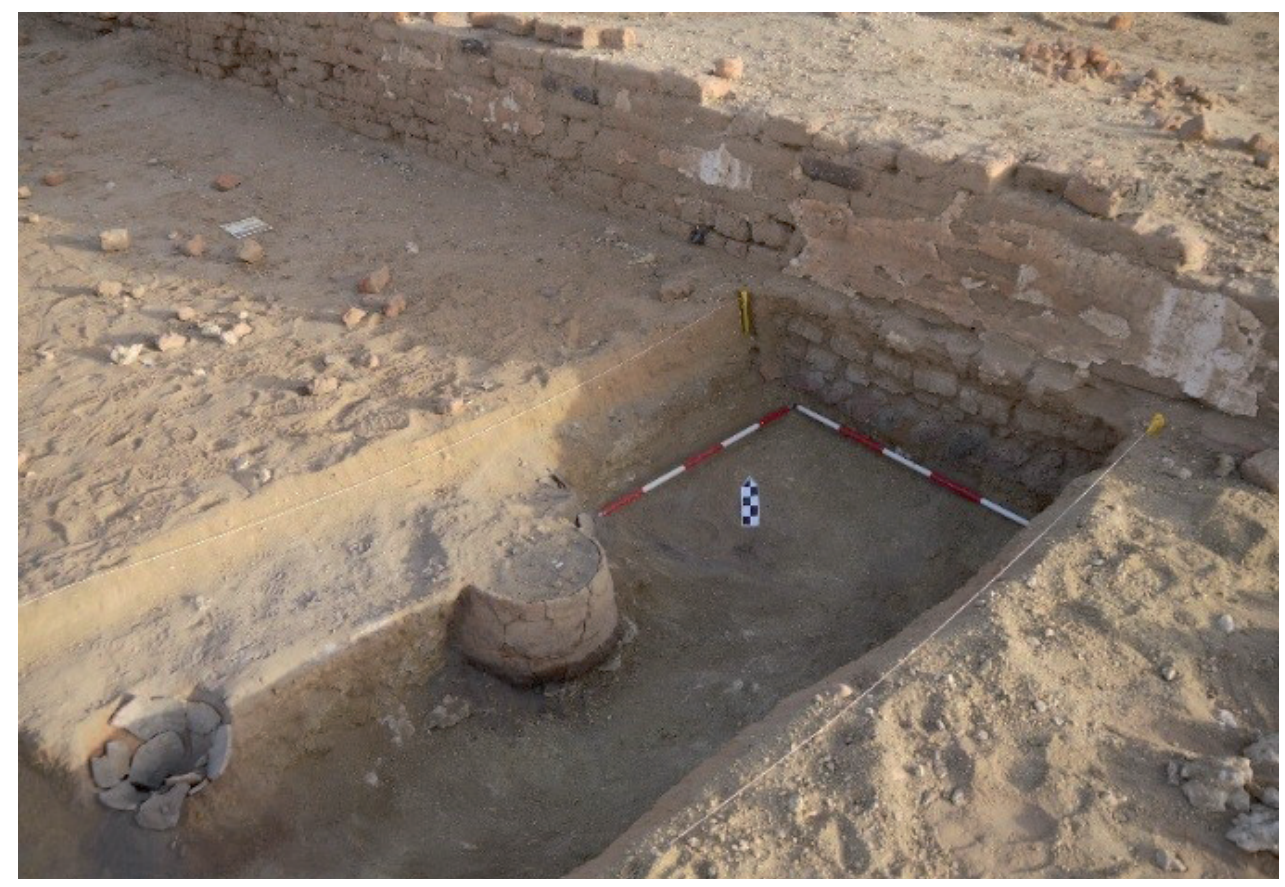

Pl. 8 Trench T60, showing the foundations of the southern exterior wall of the palace and three vessels embedded in the ground (Photo: Vlastimil Vrtal). 